\title{
Pemahaman Guru Bimbingan Konseling Tentang Nilai-nilai Religiusitas Islam dan Implementasinya dalam Bimbingan dan Konseling Kelompok
}

\author{
Cahyo Setiadi Ramadhan \\ Universitas Muhammadiyah Yogyakarta \\ cahyosetiadi@umy.ac.id \\ Siti Bahiroh \\ Universitas Muhammadiyah Yogyakarta \\ bahiroh@umy.ac.id
}

\begin{abstract}
Counseling is helpful for adolescents to overcome their problems. A good counselor needs to know the background of the counselee. The counseling based on client's background will be more successful. Therefore it is necessary to practice Islamic guidance and counseling in high schools. In addition, counselors who handle Islamic guidance and counseling activities also need to have knowledge of Islamic values. So this research will examine the understanding of guidance and counseling teachers (BK teachers) regarding Islamic values and the application of these Islamic values in group guidance and counseling activities. The research was conducted in three Islamic-based high schools in the DIY urban area. The two schools studied were six-year boarding schools with students of the same sex. The approach of the research was qualitative approach and it's data collection technique was in-depth interview. The results showed that the teacher of guidance and counseling has sufficient knowledge of Islamic values and the application of these values in Islamic guidance and counseling. The application of these values has been carried out in two forms. First, Islamic values become material in the guidance process. The second, Islamic values become a method of group guidance and counseling.
\end{abstract}

Keywords: Counseling; Guidance; Islamic Counseling; School 


\begin{abstract}
Abstrak
Konseling dapat menjadi jalan membantu remaja mengatasi masalahnya. Konselor yang baik perlu mengetahui latar belakang konseli-nya dan menerapkan pengetahui pengetahuannya tersebut dalam konseling yang dilakukan. Hal tersebut karena konseling yang menyesuikan dengan latar belakang klien akan lebih berhasil. Berdasarkan kondisi tersebut, perlu dikembangkan bimbingan dan konseling Islam di sekolah menengah atas. Selain itu, konselor yang menangani kegiatan bimbingan dan konseling Islam tersebut juga perlu menjadi perhatian, yaitu perlu memiliki pengetahuan tentang nilai-nilai Islam. Maka penelitian ini akan mengaji pemahaman guru bimbingan dan konseling (guru BK) mengenai nilai keislaman dan penerapan nilai keislaman tersebut dalam kegiatan bimbingan dan konseling kelompok. Penelitian dilaksanakan di tiga sekolah yang berbasis Islam di daerah perkotaan DIY. Dua sekolah yang diteliti merupakan sekolah berasrama enam tahun dengan siswa yang berjenis kelamin sama. Penelitian dilakukan dengan menggunakan pendekatan kualitatif dan teknik pengumpulan data berupa wawancara mendalam. Hasil penelitian menunjukkan bahwa guru BK telah memiliki pengetahuan yang memadai tentang nilai-nilai Islam dan penerapan nilai-nilai tersebut dalam bimbingan dan konseling Islam. Penerapan nilai tersebut telah dilakukan dalam bentuk nilai Islam menjadi materi dalam proses bimbingan dan nilai Islam menjadi metode dalam pelaksanaan bimbingan dan konseling kelompok.
\end{abstract}

Kata Kunci: Bimbingan; Konseling; Konseling Islam; Sekolah

\title{
Pendahuluan
}

Remaja mengalami proses perubahan dalam dirinya, pembentukan identitas sekaligus mendapatkan tuntutan dari lingkungan sekitarnya sebagai konsekuensi perkembangannya. Dalam proses perkembangan tersebut, remaja dapat mengalami deviasi dari kondisi perkembangan yang sehat atau seharusnya. Bentuk deviasi tersebut beraneka macam, seperti permasalahan psikologis, perilaku kekerasan, pelanggaran hukum remaja (juvenile delinquency), dan penyalahgunaan obat. ${ }^{1}$

\footnotetext{
1. John W. Santrock, Adolescence, Sixteenth Edition (New York: McGraw-Hill Education, 2016), 433-472.

Charles Wenar, Patricia Kerig, dan Amanda Ludlow, Developmental Psychopathology: From Infancy Through Adolescence. (New York: McGraw-Hill Education, 2012).
} 
Kondisi di Indonesia menunjukkan berbagai bentuk deviasi pada remaja perlu menjadi perhatian. Hasil pengumpulan data Masyarakat Pemantau Peradilan Indonesia Universitas Indonesia sejak 2010-2015 di pengadilan wilayah DKI menunjukkan bahwa pelaku kejahatan kebanyakan berusia muda. ${ }^{2}$ Bahkan dalam data tersebut, remaja usia 15 tahun telah terlibat dalam kasus pencurian dan pembunuhan. Sementara itu, data United Nations Children's Fund pada 2016 menunjukkan bahwa tingkat kekerasan remaja terhadap remaja lain di Indonesia yaitu 50 persen. ${ }^{3}$ Pada 2019 Badan Narkotika Nasional menyebutkan bahwa pengguna narkotika dari kalangan muda sebanyak 24-28 persen ${ }^{4}$.

Adapun kondisi kesehatan mental remaja Indonesia dapat dilihat berbagai kondisi. Berdasarkan data Riset Kesehatan Dasar 2018 diketahui remaja usia 15-124 tahun di Indonesia mengalami depresi. ${ }^{5}$ Adapun data WHO pada 2018 menunjukkan bahwa di berbagai negara berkembang, termasuk Indonesia, terdapat $15 \%$ anak dan remaja yang pernah memiliki pemikiran untuk bunuh diri. $^{6}$

Berdasarkan penjelasan tersebut, terlihat bahwa diperlukan langkahlangkah yang dapat mengatasi masalah remaja tersebut atau menghindarkan mereka dari masalah tersebut. Selain itu, diperlukan pula langkah untuk mencegah remaja terjerumus ke dalam berbagai masalah tersebut. Misal dalam konteks kesehatan mental, diperlukan langkah-langkah untuk meningkatkan kesehatan mental remaja.

Program berbasis sekolah, termasuk konseling, dapat berperan untuk mengatasi bahkan mencegah terjadinya berbagai permasalahan remaja tersebut.

2. Callistasia Anggun Wijaya, "Most crimes in Jakarta committed by youngsters: Research," terakhir diubah 22 Juni 2017, https://www.thejakartapost.com/news/2017/06/22/mostcrimes-in-jakarta-committed-by-youngsters-research.html.

3. "Kekerasan Remaja Indonesia Mencapai 50 Persen," Fakultas Kedokteran, Kesehatan Masyarakat, dan Keperawatan UGM online, 14 Maret 2018, https://fk.ugm.ac.id/kekerasanremaja-in donesia-mencapai-50-persen/

4. Puslitdatin, "Penggunaan Narkotika di Kalangan Remaja Meningkat," terakhir diubah 12 Agustus 2019, https://bnn.go.id/penggunaan-narkotika-kalangan-remaja-meningkat/

5. Badan Penelitian dan Pengembangan Kesehatan Kementerian Kesehatan RI, Laporan Riset Kesehatan Dasar 2018. (Jakarta: Kementrian Kesehatan Republik Indonesia, 2018).

6. "Meningkatnya Gangguan Mental pada Remaja, Apakah Terlalu Lama Sekolah di Rumah?” Harian Pikiran Rakyat online, 23 Juli 2020, https://jakpusnews.pikiranrakyat.com/kesehatan/pr-44632663/meningkatnya-gangguan-mental-pada-remaja-apakahterlalu-lama-sekolah-di-rumah

Gading Perkasa, "Tak Hanya Orang Dewasa, Anak Remaja Pun Bisa Mengalami Gangguan Mental", diubah terkahir 23 Juli 2020, https://lifestyle.kompas.com/read/2020/07/23/191950120/tak-hanya-orang-dewasa-anakremaja-pun-bisa-mengalami-gangguan-mental?page $=$ all. 
Program berbasis sekolah dapat menurunkan depresi siswa ${ }^{7}$ dan juga dapat meningkatan perilaku pro-sosial siswa ${ }^{8}$. Program konseling di sekolah juga dapat meningkatkan kesehatan mental siswa. ${ }^{9}$ Selain sebagai prevensi dan promosi, konseling di sekolah juga dapat menjadi kegiatan kurasi. Program konseling di sekolah dapat meningkatkankan kemampuan asertivitas penyitas perundungan ${ }^{10}$, menunrunkan pelanggaran peraturan ${ }^{11}$. Latar belakang tersebut menjadikan penting untuk terus mengembangkan program konseling di sekolah, khususnya di lembaga Pendidikan tingkat menengah yang menjadi tempat remaja mendapat pendidikan.

Urgensi pengembangan konseling tersebut berhadapan dengan kenyataan kurangnya sumberdaya dasar bimbingan dan konseling di sekolah yaitu konselor atau guru bimbingan dan konseling. Pada tahun 2013, Indonesia kekurangan 92.572 Guru Konseling. ${ }^{12}$ Asosiasi Bimbingan dan Konseling (ABKIN) sendiri menyebutkan kebutuhan guru BK sebanyak 129.000 orang. ${ }^{13}$ Untuk dapat menutupi kebutuhan tersebut, dapat dikembangkan layanan bimbingan konseling yang dapat melayani banyak siswa sekaligus.

Menurut Mulyadi ${ }^{14}$ serta Gibson dan Mitchell ${ }^{15}$, bimbingan konseling di sekolah dapat dilaksanakan dalam berbagai bentuk. Di antara berbagai bentuk

7. Sandro Corrieri, Dirk Heider, Ines Conrad, dan Anne Blume, "School-based prevention programs for depression and anxiety in adolescence: A systematic review," Health Promotion International 29, no. 3 (2013), DOI: 10.1093/heapro/dat001.

8. Hastha Purna Putra, Nurhizrah Gistituati, dan Syahniar, "Peningkatan Perilaku Prososial Siswa di Sekolah melalui Layanan Bimbingan Kelompok dengan Teknik Modeling," Jurnal Konseling dan Pendidikan 3, no. 2 (2015): 31-39, DOI: https://doi.org/10.29210/112700

9. Ahmed Elhassan Hamid Hassan, "Effectiveness of School Counseling program Based on counseling Activities to Support Mental Health among Basic School Pupils.", International Journal of Education and Research 3, no. 4 (2015): 393-400.

10. Akhmad Rifqi Azis, "Efektivitas Pelatihan Asertivitas untuk Meningkatkan Perilaku Asertif Siswa Korban Bullying," Jurnal Konseling dan Pendidikan 3, no. 2 (2015): 8-14, DOI: https://doi.org/10.29210/12500

11. Zadrian Ardi dan Mey Sisin, "The Contribution of Assertive Technique Behavioral Counseling to Minimize the Juvenile Delinquency Behavior," Jurnal Konseling dan Pendidikan 6, no. 2 (2018): 67-77. DOI: https://doi.org/10.29210/127400

12. Luki Aulia, "Sekolah Kekurangan 92.572 Guru Konseling," 23 Januari 2013, https://edukasi.kompas.com/read/2013/01/23/11190821/Sekolah.Kekurangan.92.572.Guru.K onseling.

13. "Abkin tegaskan Indonesia butuh 129.000 guru BK," Asosiasi Bimbingan dan Konseling, 29 Agustus 2013, https://www.abkin.org/news/read/96/abkin-tegaskan-indonesiabutuh-129000-guru-bk.html

Taufik Rachman, "Indonesia Butuh 129 Ribu Guru Bimbingan Konseling." terakhir diubah $30 \quad$ Agustus 2013, https://republika.co.id/berita/pendidikan/eduaction/13/05/30/mnkhvn-indonesia-butuh-129ribu-guru-bimbingan-konseling

14. Mulyadi, Bimbingan Konseling di Sekolah dan Madrasah (Jakarta: Prenadamedia Grop, 2019), 290-298. 
tersebut, yaitu penempatan dan tindak lanjut, bimbingan dan konseling individu, serta bimbingan dan konseling kelompok. Bentuk yang dapat melayani banyak siswa sekaligus dalam kaitan untuk kurasi, prevensi, dan promosi yaitu bimbingan dan konseling kelompok. Maka, perlu bentuk konseling yang perlu dikembangkan yaitu bimbingan dan konseling kelompok di sekolah menengah atas, sebagai tempat bersekolah remaja.

Pengembangan tersebut juga perlu memperhatikan kondisi remaja sebagai klien atau yang akan mengalami proses bimbingan dan konseling kelompok tersebut. Hal ini sesuai dengan pendekatan yang berkembang pada ranah konseling yaitu client-centered yang dicetuskan oleh Rogers. Pendekatan tersebut berkembang pada berbagai pendekatan konseling lain sehingga konseling dikenal cenderung memperlakukan klien setara dalam hubungan dua arah. ${ }^{16}$ Lebih jauh, aplikasi pemahaman tersebut yaitu perlunya konseling untuk sesuai dengan dunia klien, seperti kebudayaan, konteks, dan sejarah klien. Hal ini juga menjadi anjuran dalam dunia konseling. ${ }^{17}$ Kajian menunjukkan bahwa intervensi psikologis atau konseling yang menyesuaikan nilai-nilai klien akan berbuah positif. ${ }^{18}$

Penyesuaian konseling dengan dunia klien, menurut Corey ${ }^{19}$ dapat berupa akomodasi kepercayaan atau pandangan klien. Demikian juga McLeod ${ }^{20}$, menurutnya konseling perlu memperhatikan pandangan klien mengenai kenyataan atau realitas. Menurut Sue, Zane, Hall, dan Berger, penyesuaian konseling dengan dunia klien tersebut dapat pula berupa aplikasi kegiatan konseling yang lebih sesuai dengan dunia klien. ${ }^{21}$ Adapun kebanyakan remaja di Indonesia $(88 \%)$ beragama Islam. ${ }^{22}$ Berdasarkan kondisi tersebut, sebagaimana pendapat Rasool, perlu dikembangkan konseling Islam. Dalam konteks penelitian ini yaitu konseling dan bimbingan kelompok Islami atau bernuansa Islam. Di sisi lain, religiusitas atau agama sendiri terlihat memiliki

15. Robert L. Gibson dan Marianne H. Mithcell, Bimbingan dan Konseling Edisi Ketujuh, Terj. Yudi Santoso (Pustaka Pelajar: Yogyakarta, 2011), 47-316.

16. Gerard Corey, Theory and Practice of Counseling and Psychotherapy, Tenth Edition (Boston: Cengage Learning, 2016), 149-192.

John McLeod, Introduction to Counselling, Fifth Edition (New York: Open University Press, 2013), 171.

17. Courtland. C. Lee, Elements of culturally competent counseling (ACAPCD-24) (Alexandria, VA: American Counseling Association, 2008).

18. Stanley Sue, Nolan Zane, Gordon C. Nagayama Hall, and Lauren K. Berger, "The Case for Cultural Competency in Psychotherapeutic Interventions. Annual Review of Psychology, 60 (2009): 525-548. DOI: 10.1146/annurev.psych.60.110707.163651

19. Corey, 26.

20. McLeod, 287.

21. Sue, dkk.

22. Badan Pusat Statistik (BPS), Penduduk Indonesia: Hasil Sensus Penduduk Indonesia 2010 (Jakarta: Badan Pusat Statistik, 2010). 
Ajaran Islam memiliki dimensi keyakinan, perilaku, dan hukum. Syaltut menjelaskan bahwa Islam terdiri dari akidah dan syariah. Aqidah dapat dipandang sebagai tuntunan kepercayaan bagi muslim dan syariah merupakan tuntunan perilaku. ${ }^{23}$ Menurut Ismail ${ }^{24}$, ajaran Islam terbagi menjadi tiga bagian utama yaitu aqidah (akidah), syari'ah (syariah), dan akblaq (akhlaq). Akidah adalah meyakini rukun iman, syariah yaitu menjalankan rukun Islam, dan akhlak merupakan manifestasi dari ihsan. Ketiganya merupakan satu kesatuan. Serupa dengan penjelasan tersebut, Zarkasyi ${ }^{25}$ menjelaskan bahwa individu menjalani keislaman dari ritual (rukun Islam), berislam tingkat Iman, dan berislam tingkat Ihsan, dengan menambahkan satu tingkatan lagi yaitu intelektual. Selain menambahkan satu bagian, yaitu transformasi keislaman menjadi cara pandang terhadap dunia., Zarkasyi juga menganggap bagian-bagian tersebut sebagai tingkatan keislaman yang perlu ditapaki semua muslim untuk kesempurnaan Islam-nya.

Penerapan konseling sendiri membutuhkan konselor yang memenuhi kulifikasi. Menurut Gibson \& Mithcell, setidaknya konselor harus terlatih, berkomitmen, dan taat etika. ${ }^{26}$ McLeod menyebutkan beberapa proses menjadi konselor yaitu terlatih, menjalani konseling, dan mendapatkan supervisi. ${ }^{27}$ Corey berpendapat bahwa karakteristik konselor yaitu berusaha memiliki keperibadian yang sehat, berkomitmen, menjalani konseling, memahami dan terbuka pada kepercayaan lain. ${ }^{28}$

Konselor yang memenuhi kriteria merupakan hal yang juga penting dalam Bimbingan dan Konseling Islam, bahkan termasuk anjuran Islam ${ }^{29}$. Mengutip Tohirin dan Adz-Dzaky, menurut Mulyadi setidaknya konselor harus memiliki kompetensi, terdidik, serta moral dan keperibadian yang baik. Termasuk dalam kompetensi tersebut yaitu penguasaan berbagai materi yang terkait dengan konseling ${ }^{30}$. Dalam karakteristik konselor yang telah disebutkan sebelumnya, dapat kita katakan bahwa salah satu karakateristik konselor yaitu memiliki pengetahuan. Hal penting yang perlu diketahui konselor Islam tentu nilai-nilai keislaman yang akan menjadi landasannya dalam melakukan bimbingan dan konseling. Pengetahuan sendiri salah satu dimensi dalam religiusitas yang juga seyogyanya dikembangkan oleh Konselor sebagaimana yang telah diterangkan oleh Mulyadi tersebut.

23. Mahmud Syaltut, Islam Aqidah wa Syari'ah (Kairo: Dar al-Qalam, 1966), 32

24. Asep Usman Ismail, “Integrasi Syariah dengan Tasawuf” Ahkam XII, no.1 (2012): 129138. DOI: $10.15408 /$ ajis.v12i1.987

25. Hamid Fahmi Zarkasyi, Minhaj: Berislam, dari Ritual hingga Intelektual. (Jakarta: Inisist, 2020).

26. Gibson dan Mithcell, 45.

27. McLeod, 588-612.

28. Corey, 19-26.

29. Mulyadi, 268.

30. ibid, 230-268. 
Berdasarkan latar belakang yang telah diterangkan, diketahui bahwa konseling dapat menjadi jalan mengatasi masalah remaja. Konseling tersebut, seyogyanya disesuaikan dengan latar belakang konseli. Remaja di Indonesia yang mayoritas Islam menjadikan perlu untuk menelaah implementasi nilai-nilai keislaman dalam konseling. Di sisi lain, kompetensi konselor penting juga dalam kesuksesan konseling. Pengetahuan konselor mengenai latar belakang konseling juga penting. Menimbang rangkuman dari latar belakang tersebut, penelitian ini mengaji mengenai pemahaman guru bimbingan konseling (BK) sebagai konselor, tentang nilai-nilai religiusitas Islam. Pemahaman tersebut akan dikaitkan dengan implementasi nilai religiusitas Islam dalam kegiatan bimbingan dan konseling kelompok yang mereka lakukan. Dengan demikian, tujuan penelitian ini yaitu sebagai berikut:

1. Mendeskripsikan pemahaman guru bimbingan konseling tentang nilai-nilai religiusitas Islam dan upaya mereka mendapatkan atau meningkatkan pemahaman mengenai nilai religiusitas Islam tersebut.

2. Mendeskripsikan implementasi nilai-nilai religiusitas Islam dalam kegiatan bimbingan dan konseling kelompok yang dilakukan guru bimbingan konseling.

Metode penelitian yang digunakan adalah kualitatif dengan pendekatan studi kasus. Penelitian dilakukan di Sekolah berbasis Islam yang menyelenggarakan bimbingan dan konseling kelompok oleh guru BK. Sekolah yang dipilih menjadi tempat penelitian yaitu tiga sekolah menengah atas yang merupakan tempat remaja menempuh pendidikan. Sekolah tersebut yaitu sekolah X, Y, Z. Ketiga sekolah tersebut semua berada di lingkungan perkotaan di Daerah Istimewa Yogyakarta. Sekolah X berada di bawah naungan Kementrian Pendidikan dan Kebudayaan Republik Indonesia. Adapun dua sekolah lainnya berada di bawah naungan Kementrian Agama Republik Indonesia. Sekolah yang berada di bawah naungan Kementrian Agama Republik Indonesia bersistem asrama, memiliki murid hanya dari satu jenis kelamin, dan memiliki sistem 6 tahun atau tingkat Madrasah Tsanawiyah hingga Aliyah. Walaupun demikian, pelaksanaan bimbingan dan konseling untuk tingkat pendidikan yang berbeda ditangani oleh guru BK yang berbeda pula.

Pengumpulan data dilakukan dengan wawancara semi terstruktur yang menanyakan tentang pemahaman mengenai nilai-nilai religiusitas Islam dan implementasi nilai religiusitas tersebut dalam bimbingan dan konseling kelompok. Selain itu, ditanyakan juga mengenai latar belakang guru BK sebagai informan yaitu keaktifan dalam kegiatan Islam, kegiatan meningkatkan pemahaman Islam, dan latar belakang keilmuan. Wawancara dilakukan beberapa kali pada Juli-September 2020. Kegiatan ini dilakukan secara langsung sehingga ketika terjadi wabah, kegiatan dilakukan dengan mematuhi protokol kesehatan. 
Informan dalam penelitian ini adalah mereka yang memiliki kriteria (1) Guru BK atau menyelenggarakan Bimbingan dan Konseling Kelompok. Mereka yaitu (1) lima Guru BK dari Sekolah X, (2) lima guru BK dari sekolah Y, dan (1) 1 guru BK dari Sekolah Z. Data-data yang diperoleh dilapangan terlebih dahulu dikelompokkan berdasarkan kualitas dan kategorinya. Kategori data mengacu jenis-jenis pemahaman tentang nilai nilai religiusitas agama, kategori data implementasi nilai-nilai religiusitas dalam konseling kelompok. Data-data yang sudah dikategorikan, kemudian dianalisis dan diinterpretasikan dengan menggunakan pola berfikir deduktif. Hasil analisis kemudian disusun secara sistematis dalam bentuk laporan dengan model deskriptif analitik

\section{Hasil dan Pembahasan}

\section{Pemahaman Guru Bimbingan dan Konseling Tentang Nilai-Nilai Religiusitas Islam}

Semua Informan menunjukkan pengetahuan dan pemahaman yang memadai mengenai nilai-nilai religiusitas Islam terkait aqidah (keyakinan), akhlak (tata perilaku), dan syariah (aturan beribadah dan berhubungan dengan orang lain).Ketika ditanyakan untuk menjelaskan hal-hal yang perlu diyakini seorang Muslim, semua informan menjawab dengan menyebutkan poin-poin rukun iman yaitu percaya kepada Allah, percaya adanya malaikat, percaya mengenai kitabkitab, percaya mengenai nabi-nabi, percaya mengenai Hari Akhir, dan percaya kepada taqdir Allah atau ada juga yang menyebut percaya kepada qadha dan qadar Allah, dan terdapat pula yang menyebutkan percaya kepada ketentuan Allah yang baik dan buruk. Ketika dilakukan probing atau meminta informan menceritakan lebih lanjut mengenai keyakinannya sebagai Muslim, Ibu $\mathrm{R}^{31}$ menyebutkan sebagai berikut.

"...ya meyakini adanya Allah yang menciptakan dunia dan seisinya serta mangatur dunia ini. Sehingga Allah yang mengetahui segala mengenai dunia ini dan memberikan tuntunan melalui Al-Quran... Kita juga mempercayai nabinabi tersebut dan khususnya Nabi Mubammad, menjadi panutan dan teladan kita."

Pak Y menyebutkan bahwa ${ }^{32}$,

"Iman kepada Allah ini menjadi bal yang melekat kepada kita sejak labir. ....Nah, saat kita menjalani hidup di dunia kadang kita menjadi ingkar kepada kekuasaan Allah. Babkan terkadang kita menjadi menganggap ada kekuatan lain yang setara dengan Allah. Kalau sudah demikian maka kita bisa jatub kepada syirik"

\footnotetext{
31. Wawancara dengan Ibu R pada 14 Juli 2020

32. Wawancara dengan Pak Y pada 18 Agustus 2020
} 
Pak D menjelaskan lebih lanjut mengenai keyakinannya mengenai malaikat. Menurutnya keyakinan mengenai malaikat ini juga termasuk meyakini adanya tugas-tugas malaikat sepert mencatat amalan baik dan buruk manusia. ${ }^{33}$ Adapun Ibu $G$ menyebutkan keyakinannya akan Al-Quran sebgai tuntunan hidup bagi muslim. Menurutnya, Al-Quran perlu dibaca terus menerus karena selain sebagai tuntunan, membaca Al-Quran dapat membuat hati menjadi tenang ${ }^{34}$. Ibu B menyatakan ${ }^{35}$,

"Iman kita kepada Allah, kepada malaikat itu dapat menjadikan kita tenang. Misal kita sedang gusar karena kebaikan kita tidak dianggap orang lain, kalau kita percaya adanya malaikat tentu kita akan yakin bahwa perilaku baik. kita dicatat malaikat. Jadi Allah tahu dan akan membalas kebaikan kita. Demikian pula ketika kita akan melakukan kejelakan, karena kita yakin Allah mengentabui kita tidak.jadi melakukan kejahatan."

Ibu S menyebutkan bahwa ${ }^{36}$

"Keimanan kepada hari akbir itu dapat menjadikan kita tenang menjalani kehidupan ini. Jika ada orang suka menyakiti kita atau berbuat salab kepada kita, pasti akan mendapatkan bukuman di Hari Akbirat. Jika dia bertobat juga, kita akan mendapatkan tambaban ganjaran baik.”

Semua informan menyampaikan bahwa mereka sudah merasa memiliki keyakinan atau aqidah yang benar. Adapun mengenai akhlaq atau tuntunan cara berperilaku dalam Islam, semua informan meyakini terdapat aturan-aturan cara berperilaku dalam Islam. Mereka juga menyatakan bahwa tuntunan tersebut terdapat di dalam Al-Quran dan Hadits Nabi. Ibu A menyebutkan bahwa ${ }^{37}$,

“...misalnya Islam mengajarkan agar tidak berburuk sangka. Islam mengatur juga pergaulan sesama muslim, dengan non-muslim, dengan orang bukan mubrim, berbakti pd orang tua. Islam juga mengajarkan tidak sombong, tidak dendam, tidk riya', tidak mudah marah, tidak mudah bersedib."

Salah seorang informan yaitu Ibu F menyebutkan juga mengenai akhalq kepada Allah. Menurutnya ${ }^{38}$,

"Kepercayaan kita kepada Allah juga termasuk kita beribadah dengan baik kepadaNya, seolah-olah kita bisa melihat Allah. Itu disebut ibsan, itu juga merupakan akblaq kita kapada Allah sebingga kita senantiasa merasa dekat kepada-Nya"

\footnotetext{
33. Wawancara dengan Pak D pada 20 Agustus 2020

34. Wawancara dengan Pak G pada 28 Agustus 2020

35. Wawancara dengan Ibu B pada 7 Juli 2020

36. Wawancara dengan Ibu S pada 12 Agustus 2020

37. Wawancara dengan Ibu A pada 2 Agustus 2020

38. Wawancara dengan Ibu F pada 10 Juli 2020
} 
Semua informan merasa sudah menjalankan akhlak yang baik dalam bergaul. Sedangkan mengenai syariah, semua informan mengetahui dan meyakini adanya aturan hukum di dalam Islam yang terdapat di dalam Al-Quran dan Hadits. Ibu $\mathrm{H}$ menyebutkan perbedaan aturan hukum dengan akhlak yaitu untuk hukum itu mengenai hal-hal yang boleh atau tidak sedangkan akhlak yaitu tentang yang baik dan buruk. Menurutnya baik hukum maupun akhlak menjelaskan mengenai cara berperilaku namun hukum juga menjelaskan mengenai bentuk-bentuk ibadah atau ritual. Kebanyakan informan sudah merasa mentaati syariat. ${ }^{39}$ Adapun Pak D dan Ibu G merasa terkadang masih melanggar syariat.

Bapak D menjelaskan ${ }^{40}$ : "...ya kalau menjalankan tuntunan agama atau bukum agama dengan baik itu kita merasa lebih tenang. Sedangkan kalau melanggar itu merasa resah karena takut dosa soalnya”. Para guru BK yang menjadi informan juga menyatakan pentingnya nilai Islam dalam kehidupan. Ibu B ${ }^{41}$ menyatakan: "Bagi saya nilai-nilai religiusitas agama itu sangatlah penting untuk, kita amalkan sehari-bari di sekolah, ..." Selaras dengan Ibu B, salah satu Ibu $\mathrm{R}^{42}$ menyatakan bahwa : "... sebagai guru BK, nilai-nilai religiusitas itu penting, ...".

Berdasarkan deskripsi tersebut, dapat kita katakan bahwa semua informan memiliki pemahaman yang memadai mengenai nilai-nilai religiusitas Islam, baik secara keyakinan, tuntunan perilaku, maupun hukum. Pemahaman pada pokok-pokok nilai menunjukkan pemahaman para informan yaitu guru BK mengenai niliai-nilai religiusitas Islam. Hal dikarenakan niliai-niliai tersebut dapat dikatakan sudah mencakup nilai-nilai religiusitas Islam secara umum. ${ }^{43}$

Beberapa informan merasa bahwa pemahaman mereka mengenai nilainilai religiustias Islam, khususnya mengenai hukum, kurang dapat mereka aplikasikan dalam bentuk perilaku. Hal tersebut tidak dianggap mengurangi tingkat pemahaman mereka karena walaupun menjadi satu dalam keberagamaan, pemahaman dan pengamalan agama menjadi dua aspek yang berbeda. Adapun penelitian ini mengaji mengenai aspek pemahaan nilai religiusitas. Glock dan Stark mengemukakan lima aspek religiusitas yang diadopsi oleh Ancok dan Nashori menjadi aspek religiusitas Islam. ${ }^{44}$ Pengamalan nilai-nilai, termasuk religiusitas Islam, juga menjadi perhatian dalam sebuah proses konseling baik individual, kelompok, maupun sistem. ${ }^{45} \mathrm{Hal}$ tersebut akan dijelaskan pada bagian lanjut.

\footnotetext{
39. Wawancara dengan Ibu $\mathrm{H}$ pada 9 Juli 2020

40. Wawancara dengan Pak D pada 20 Agustus 2020

41. Wawancara dengan Ibu B pada 7 Juli 2020

42. Wawancara dengan Ibu R pada 14 Juli 2020

43. Syaltut, 32; Ismail; Zarkasyi.

44. Djamalludin Ancok dan Fuat Nashori Suroso, Psikologi Islami: Solusi Islam atas Problem-problem Psikologi (Yogyakarta: Pustaka Pelajar, 2011), 76-82.

45. Mulyadi, 243
} 


\section{Upaya Konselor Islam di Sekolah Islam Untuk Memahami Nilai-Nilai Religiusitas Islam}

Selain membahas hasil kajian utama, pemahaman guru BK mengenai nilai-nilai Religiusitas Islam dan implementasi nilai-nilai Religiusitas Islam tersebut, akan dibahas juga mengenai latar belakang informan yang terkait dengan bahasan utama. Terkait mengenai pemahaman akan nilai-nilai religiusitas Islam, dibahas mengenai kesertaan dalam kegiatan keislaman dan upaya meningkatkan pemahaman akan nilai-nilai keislaman.

Sebanyak 10 dari 11 informan menyatakan aktif di organisasi keislaman. Adapun 1 orang informan menyatakan tidak aktif tetapi telah tergabung dan mengikuti berbagai kegiatan organisasi Islam tempatnya bergabung walaupun tidak selalu. Dapat dikatakan bahwa informan tergabung dalam organisasi Islam dan cenderung aktif dalam kegiatan keislaman. Waktu atau durasi lama mereka bergabung dalam organisasi tersebut beragam, 4 infoman telah aktif lebih dari 10 tahun, 4 informan mengikui organisasi keislaman selama sekitar 6 atau 7 tahun, dan 3 informan telah aktif sekitar 1-2 tahun. Sebagian informan menjadi pengurus tingkat lokal dan tingkat yang lebih luas di organisasi keislaman yang diikutinya.

Mengenai sumber pemahaman nilai-nilai religiusitas, hasil wawancara dengan semua informan guru BK baik di Sekolah Y, X, maupaun Z menunjukkan bahwa mereka mendapatkan pemahaman mengenai nilai-nilai Islam dari berbagai sumber.

a. Membaca majalah, buku, surat kabar

Membaca merupakan salah satu langkah Ibu F menambah pemahamannya mengenai nilai-nilai religiusitas ${ }^{46}$

"Membaca majalah keislaman merupakan hal yang rutin saya lakukan karena syarat dengan nilai-nilai religiusitas, misalnya pada kolom "Kalam", Konsultasi, Hikmah, juga kolom kesehatan. Disitulah kita dapatkan hikmah dari nilai-nilai keTubanan".

Membaca buku buku agama juga menjadi kegiatan rutin sebagaimana yang dilakukan oleh Ibu B ${ }^{47}$ dengan penuturannya,

"Di Sekolah ini disediakan banyak sekali buku buku agama yang bisa dibaca oleh siapapun, seperti buku buku badist Nabi, tafsir al-Qur'an, juga buku buku akblak. Babkan secara spesifik ada buku buku yang membahas tentang fiqib perempuan, adabul mar'ah fil Islam, dll'.

\footnotetext{
46. Wawancara dengan Ibu F pada 10 Juli 2020

47. Wawancara dengan Ibu B pada 7 Juli 2020
} 
Ibu $\mathrm{R}$ juga menyatakan bahwa di sekolah (yaitu Sekolah X) banyak tersedia buku-buku bacaan baik majalah, buku agama, buku umum, sehingga pada jam jam longgar, ia bisa membaca. Pada jam istirahat, biasanya Ibu R membaca buku terutama yang terkait dengan hadist-hadist tentang akhlak dan kedisiplinan. ${ }^{48}$

b. Diskusi

Para informan menyatakan bahwa mereka berdiskusi dengan teman mengenai keislaman. Diskusi mengenai nilai-nilai religiusitas di sekolah berbasis Islam juga sering dilakukan meskipun bentuknya tidak selalu formal. Ketika ada berita berita yang berkaitan dengan moralitas remaja, seperti klithih, penyimpangan sexual, pemerkosaan, perampokan, pesta miras, guru BK sering berkumpual mendiskusikan peristiwa tersebut dari sudut pandang Islam sehingga menambah pemahaman mengenai nilai keislaman. ${ }^{49}$

c. Pengajian

Selain membaca, para guru BK mendapatkan pemahaman tentang nilainilai agama melalui pengajian langsung. Biasanya pengajian ini diadakan oleh sekolah, paguyuban guru BK, bahkan dari organisasi keislaman yang diikuti. Menurut Bapak E, pengajian yang diselenggarakan oleh organisasi keislaman biasanya dalam bentuk: kajian tafsir, hadis, tadarus, dan pengajian umum dengan metode ceramah dan tanya jawab. ${ }^{50}$ Baik di Sekolah X maupun di Sekolah Y, ada pengajian rutin setiap bulan yang diikuti oleh semua guru.

d. Training, Workshop, atau Pelatihan

Kegiatan workshop terkait dengan nilai-nilai religiusitas ini menurut Ibu $\mathrm{R}$, selalu diadakan secara periodik. Hal ini dilakukan agar para guru baik yang mengajar di kelas maupun guru BK mendapatkan pencerahan agama. ${ }^{51}$ Menurut Ibu P di Sekolah Y training ai-Islam diadakan setahun 2 kali. $^{52}$

Berdasarkan keterangan informan, terlihat bahwa informan cenderung berusaha untuk meningkatkan pengetahuan mereka mengenai nilai-nilai religiusitas Islam dengan berbagai saluran yang telah disebutkan sebelumnya. Hanya satu informan yang mengikuti informasi atau konten yang memambah pengetahuan keislaman sebanyak 1-7 kali sebulan. Informan lain mengikuti informasi tersebut melalui media atau diskusi antara belasan hingga 30 kali. Bahkan dua informan mengikuti konten keislaman melalui media sebanyak lebih dari 30 kali perbulan.

\footnotetext{
48. Wawancara dengan ibu $\mathrm{R}$ pada 3 Agustus 2020

49. Wawancara dengan Ibu A pada 2 Agustus 2020

50. Wawancara dengan Bapak E pada 21 Juli 2020

51. Wawancara dengan Ibu R pada

52. Wawancara dengan Ibu P pada 26 Agustus 2020
} 
Adapun frekuensi keikutsertaan dalam pengajian, training, atau workshop keislaman kebanyakan antara 4 sampai 12 kali bahkan dua informan mengikuti kegiatan sejenis lebih dari 12 kali sebulan. Para infomorman setidaknya hampir setiap pekan mendapatkan ilmu keislaman dari pengajian, training, atau workshop. Hal tersebut, juga didiukung sekolah atau organisasi keislaman yang mereka ikuti yang mengadakan kegiatan-kegiatan tersebut sehingga para informan berkesempatan untuk menambah pengetahuan mereka tentang nilai-nilai religiusitas Islam.

Penjelasan tersebut menunjukkan bahwa informan, juga memiliki tingkat religiusitas yang baik dalam dimensi konsekuensial (pengamalan). ${ }^{53}$ Responden ikut serta aktif dalam kegiatan keagamaan. Hal ini melengkapi dan memperkuat keterangan sebelumnya yaitu informan memiliki religiusitas yang baik dalam dimensi pengetahuan dan keyakinannya. Informan juga menunjukkan perilaku meningkatkan keilmuan Islam yang bermanfaat bagi kegiatan bimbingan dan konseling yang dilakukan. Kondisi ini menunjukkan guru BK yang menjadi informan telah memenuhi salah satu kriteria konselor yaitu meningkatkan kemampauan dan pengetahuan. ${ }^{54}$ Ini semakin menunjukkan bahwa guru BK yang menjadi informan memenuhi kriteria konselor.

Selain itu juga dibahas mengenai latar belakang pendidikan informan yang semakin menunjukkan pemenuhan informan mengenai kriteria atau karakteristik konselor/guru BK yang telah disebutkan sebelumnya ${ }^{55}$ Diketahui bahwa para informan yang berasal dari sekolah di bawah Kementerian Pendidikan dan Kebudayaan cenderung memiliki latar belakang pendidikan konseling atau psikologi. Diketahui 3 informan dari sekolah tersebut berlatar belakang pendidikan konseling dan 2 informan berlatar pendidikan psikologi bahkan salah satunya telah menempuh pendidikan magister.

Adapun informan dari sekolah di bawah Kementerian Agama berlatar belakang Pendidikan konseling atau psikologi yang diperkaya atau dengan ciri khas keislaman. Diketahui 1 orang informan dari sekolah tersebut berlatar belakang pendidikan konseling, 1 informan berlatar pendidikan psikologi, 1 informan berlatar pendidikan konseling Islam, 1 informan berlatar belakang magister dalam bidang konseling Islam, 1 informan berlatar belakang pendidikan magister dalam bidang psikologi Islam, dan 1 orang belatar belakang pendidikan magister psikologi.

Setelah lulus dari Pendidikan, guru BK juga terus melakukan peningkatan kemampuan dalam hal bimbingan dan konseling. Misalnya Ibu $\mathrm{S}^{56}$ menjelaskan juga bahwa kendati informasi itu bisa dengan mudah didapatkan

\footnotetext{
53. Ancok dan Suroso, 76-82

54. Gibson dan Mithcell, 45; McLeod, 588-612; Corey, 19-26.

55. Ibid.

56. Wawancara dengan Ibu S pada 12 Agustus 2020
} 
dari gawai (gadget), namun rasanya kurang mantab untuk meningkatkan pengetahuan fenomena terkait dengan BK melaui sumber tersebut saja. Sehingga, menurutnya, perlu juga membaca mengenai tema konseling atau bimbingan di surat kabar harian.

\section{Implementasi Nilai-Nilai Religiusitas Dalam Bimbingan dan Konseling Kelompok}

Penjelasan para guru BK mengenai pentingnya nilai-nilai religiusitas Islam juga diikuti dengan pernyataan mereka mengenai pentingnya nilai-nilai tersebut dalam proses bimbingan dan konseling di sekolah. Ibu $\mathrm{B}^{57}$ menyatakan,

"Nilai-nilai religiusitas itu juga harus bisa kita ajarkan, kita sosialisasikan, sekaligus diterapkan kepada anak didik...di sekolah ini tentunya mengacu pada nilai-nilai religiusitas Islam."

Demikian pula salah Ibu $\mathrm{R}^{58}$ menyatakan bahwa : “..., babkean di sekolah berbasis Islam ini para guru harus memikirkan moral, tingkah laku dan sikap dari peserta didik". Ibu $\mathrm{F}^{59}$ juga memberikan gambaran bahwa jika kita fahami Negara Indonesia berdasarkan ke-Tuhanan, maka di Sekolah Y, seluruh guru harus membawa anak didik ke arah menumbuhkan jiwa ke-Tuhanan. Hal tersebut dalam arti kepribadian dan sikap jiwa anak didik harus dapat mengendalikan tingkah lakunya dengan cara-cara yang sesuai dengan tuntunan agama Islam.

Ibu $G$ dan Pak D yang ditemui secara terpisah terpisah, juga mengatakan pentingnya penerapan nilai-nilai religiusitas agama pada siswa dengan metode pembiasaan pengamalan agama di sekolah seperti disiplin, shalat tepat waktu, menghormati guru, berbagi dengan sesama, dan lain-lain. Hal tersebut akan membantu memelihara moral siswa, sehingga akan lahir para sarjana yang dapat memberikan manfaat kepada masyarakat, bukan sarjana yang menggunakan ilmu dan kepintarannya untuk mencari keuntungan semata, tanpa memikirkan dan merasakan apa yang menimpa orang banyak. ${ }^{60}$

Ibu A juga menyatakan bahwa sebagai guru BK di sekolah harus benar benar faham tentang nilai-nilai religiusitas, karena merupakan fondasi atau panduan dalam membimbing anak, meskipun dalam membimbing itu juga perlu ilmu ilmu lain seperti psikologi, sosiologi, dan lain lain. ${ }^{61}$ Terlihat bahwa para guru BK yang menjadi informan menganggap aplikasi nilai-nilai keislaman dalam melakukan kegiatan bimbingan dan konseling di sekolah, perlu dilakukan bahkan sangat penting.

\footnotetext{
57. Wawancara dengan Ibu B pada 7 Juli 2020

58. Wawancara dengan Ibu R pada 14 Juli 2020

59. Wawancara dengan Ibu F pada 10 Juli 2020

60. Wawancara dengan Ibu G dan Pak D pada waktu yang berbeda

61. Wawancara dengan Ibu A, 2 Agustus 2020
} 
Pemahaman mengenai pentingnya nilai-nilai religiusitas Islam tersebut mendukung religiusitas guru-guru BK tersebut, yaitu pada dimensi komitmen dan keyakinan berdasarkan dimensi religiusitas menurut Glock dan Stark. ${ }^{62}$ Para informan juga menyebutkan berbagai nilai dalam Islam yang dapat diaplikasikan dalam kegiatan konseling. Penjelasan mereka tersebut sering muncul saat menjelaskan mengenai nilai-nilai religiusitas yang mereka pahami. Mereka sudah menyebutkan aplikasi berbagai nilai tersebut untuk mendapatkan ketenangan atau kenyamanan di dalam hidup. Berbagai pernyataan tersebut juga dapat dilihat pada penjelasan sebelumnya mengenai pemahaman informan mengenai nilai religiusitas Islam. Ibu R menyatakan ${ }^{63}$,

"Allah ... memberikan tuntunan melalui Al-Quran. Nah, itu bisa kita gunakan untuk menjadi panduan kita dalam mendidik siswa, misal membina siswa sesuai akblaqul karimah."

Ibu A menyebutkan berbagai akhlak mulia yang perlu diajarkan kepada siswa sehingga dapat mendorong siswa untuk berperilaku baik dan menghindari atau mengatasi masalah. ${ }^{64}$,

"...ajaran Islam seperti berbaik sangka, bersikap baik dengan sesama muslim dan non-muslim, menjaga sikap dengan yang bukan mubrim, berbakti pd orang tua., tidak sombong, tidak dendam, tidak riya', sabar dan lain sebagainya itu bis akita ajarkan atau sampaikan kepada siswa sehingga mereka dapat memiliki perilaku yang baik atau juga dapat menjadi solusi bagi masalah yang mereka badapi."

Adapun Ibu B menyebutkan keimanan kepada Allah dan malaikat dapat mendorong siswa untuk berperilaku baik sehingga perlu diajarkan. ${ }^{65}$

"Kepercayaan kita mengenai Allah ataupun malaikat yang selalu mengawasi kita juga dapat kita sampaikan kepada siswa sehingga mereka termotivasi untuk mengatur perilaku atau memunculkan perilaku yang baik. tanpa barus kita awasi terus. Itu bisa saat pertemuan sendiri ataupun saat focused group discussion atau bimbingan dan konseling kelompok terbadap siswa yang memiliki kasus yang mirip."

Nilai religiusitas Islam yang menurut Ibu S dapat disampaikan kepada siswa dan dapat membantu mereka memunculkan perilaku yang baik yaitu keyakinan kepada hari akhir. ${ }^{66}$

"Keyakinan kepada hari akhir yang dapat menjadikan kita santai atau tenang menjalani bidup ini juga mungkin perlu ditanamkan kepad siswa yang sedang menghadapi masalah. Dengan pikirannya yang berubah maka cara dia memandang masalab akan berubah."

\footnotetext{
62. Ancok dan Suroso, 76-82

63. Wawancara dengan Ibu R pada 14 Juli 2020

64. Wawancara dengan Ibu A pada 2 Agustus 2020

65. Wawancara dengan Ibu B pada 7 Juli 2020

66. Wawancara dengan Ibu S pada 12 Agustus 2020
} 
Penyebutan berbagai nilai keislaman yang dapat diterapkan dalam bimbingan dan konseling kepada siswa tersebut menunjukkan tingkat kepahaman klien mengenai aplikasi nilai dalam konseling. Sebagaimana yang telah dijelaskan, hal tersebut merupakan suatu hal yang penting dalam konseling yang disesuaikan dengan nilai-nilai klien. ${ }^{67}$ Baik Ibu B maupun Ibu S pada kutipan di atas juga menyebutkan cara-cara penyampaian nilai-nilai yang mereka sebutkan kepada siswa. Ini menunjukkan pemahaman konselor mengenai metode konseling sendiri dan juga merupakan hal yang penting dalam konseling. ${ }^{68}$

Cara yang telah disebutkan yaitu bimbingan atau konseling individual, focused group discussion yang merupakan salah satu bentuk bimbingan dan konseling kelompok, dan pengubahan pola pikir yang dapat digolongkan dalam pendekatan kognitif. Pendekatan kelompok yang disebutkan juga dapat digolongkan sebagai konseling kelompok problem solving. ${ }^{69}$ Pendekatan kognitif memiliki banyak kesamaan dengan nilai-nilai religiusitas Islam sehingga banyak dikembangkan oleh cendikiawan muslim sebagai dasar konseling menggunakan nilai-nilai religiusitas Islam. ${ }^{70}$

Beberapa informan juga menyebutkan mengenai nilai-nilai keislaman yang tidak hanya menjadi konten tetapi menjadi metode dalam konseling dan bimbingan siswa. Dengan pemahaman akan nilai-nilai religiusitas Islam dan pemahaman mengenai konseling, dapat dirumuskan proses bimbingan dan konseling yang lebih akrab dengan siswa dan dilandasi nilai-nilai religiusitas Islam. Hal ini merupakan salah satu langkah dalam penyesuaian konseling dengan klien. ${ }^{71}$ Pak E menjelaskan ${ }^{72}$,

“...Nabi Mubammad, menjadi panutan dan teladan kita. Ini termasuk dalam mendidik siswa kita mengikuti akblak. Nabi, misalnya sabar dan dapat menjadi teladan atau uswah hasanah bagi siswa."

Pernyataan tersebut menunjukkan bahwa nilai keislaman yang diterapkan atau diamalkan guru BK dapat menjadi jalan untuk mentransfer nilai tersebut

67. Sue, dkk; Corey, 26 .

68. Gibson dan Mithcell, 45; McLeod, 588-612; Corey, 19-26.

69. Gibson dan Mithcell, 275

M. Fatchurahman, Dina Fariza Triyani Syarif, dan Siti Turohmi, "Efektivitas Layanan Konseling Kelompok Menggunakan Teknik Problem Solving Dalam Menurunkan Perilaku Membolos Siswa", Indonesian Journal of Educational Counseling 2, no.1 (2018): pp. 55-68

Bakhrudin All Habsy, "Model Konseling Kelompok Cognitive Behavior Untuk Meningkatkan Self-Esteem Siswa SMK", PERSPEKTIF Ilmu Pendidikan 31, no. 1, (2017): 21 35

70. G. Hussein Rassool, Islamic Counselling: An Introduction to Theory and Practice (East Sussex: Routledge, 2016).

71. Sue, dkk.

72. Wawancara dengan Bapak E pada 21 Juli 2020 
kepada siswa. Hal ini sesuai pendekatan kognitif behavioral yang menjadikan modeling sebagai salah satu cara pendidikan. Guru BK menjadi contoh bagi siswa dalam penerapan nilai Islam juga diungkapkan Ibu $\mathrm{B}^{73}$ : “...lebib-lebih terkait dengan tugas kita sebagai guru BK yang harus memberikan contoh yang baik untuk anakanak kita."

Adapun Ibu $G$ menyebutkan nilai religiusitas berupa ibadah membaca Al-Quran dapat menjadi salah satu sarana dalam melakukan konseling terhadap siswa yang bermasalah atau bimbingan sebagai bentuk prevensi dan promosi ${ }^{74}$. Penggunakan ibadah sebagai bagian konseling Islam, misalnya coping religius, dapat dilakukan. ${ }^{75}$

"Membaca Al-Quran dapat menenangkan hati. Kita dapat menganjurkan siswa untuk banyak membaca Al-Quran saat sedang menghadapi kegundahan, dengan demikian mereka dapat merasa tenang dan dapat mengatasi masalah mereka."

Cara lain yang diungkapkan informan dalam melakukan bimbingan dan konseling yaitu pendekatan biblioterapi ${ }^{76}$ yang bertujuan memunculkan insight pada siswa sebagai klien menggunakan buku. Ibu $\mathrm{F}^{77}$ menyebutkan,

"Buku keislaman tersebut, termasuk majalah terdapat di perpustakaan dan dapat menjadi sumber informasi bagi siswa. Mereka akan memahami nilai-nilai Islam dan dapat mengaplikasikannya dalam kehidupannya".

Demikian juga Ibu B ${ }^{78}$ menceritakan,

"Di Sekolah ini disediakan banyak sekali buku buku agama yang bisa dibaca oleh siapapun, ... bisa digunakan juga oleh para siswa untuk menambah pemahaman mereka tentang ajaran Islam sehingga nantinya dapat mereka amalkan. Dengan demikian juga membantu menumbubkan perilaku yang baik pada siswa.".

Penyediaan buku mengenai Islam di perpustakaan dapat dipandang sebagai pendekatan sistem dalam melakukan bimbingan kepada siswa. Pendekatan sistem yang dimaksudkan yaitu kegiatan bimbingan dan konseling menyeluruh pada bagian-bagian sekolah yang akan memberikan dampak positif

73. Wawancara dengan Ibu B pada 7 Juli 2020

74. Wawancara dengan Ibu G pada 17 Juli 2020

75. Rasool.

${ }^{76}$ Dede R. Hidayat, Konseling di Sekolah: Pendekatan-pendekatan Kontemporer. (Jakarta: Prenada Media, 2018), 49-58.

77. Wawancara dengan Ibu F pada 10 Juli 2020

78. Wawancara dengan Ibu B pada 7 Juli 2020 
bagi siswa. ${ }^{79}$ Konseling menjadi sub bagian dari sistem pendidikan di sekolah tersebut. $^{80}$

Pendekatan sistem juga disebutkan informan lainnya yaitu peningkatan kapasitas konselor melalui diskusi sehingga mereka lebih siap menghadapi masalah-masalah siswa. Ketika ada berita berita yang berkaitan dengan moralitas remaja, menurut Ibu A, para guru berkumpul di ruang kantor, bersikusi tentang sebab dan cara penyelesain masalah tersebut dari sudut pandang Islam. ${ }^{81}$

Menurut Pak S ${ }^{82}$, kegiatan bimbingan dilakukan melalui pelibatan guru BK dalam berbagai kegiatan kelompok siswa, seperti pembinaan ekstrakurikuler, pelatihan pelatihan peningkatan ketrampilan siswa, dan lain lainnya. Dengan demikian internalisasi nilai-nilai religiusitas agama dilakukan saat proses mendampingi siswa dalam kegiatan ekstrakurikuler dan pelatihan pelatihan.

Penjelasan mengenai implementasi nilai-nilai Islam sebelumnya dalam konteks yang umum, dapat pada bimbingan dan konseling individual, kelompok, dan sistem. Hal ini menunjukkan kelengkapan layanan bimbingan dan konseling di sekolah berbasis Islam telah memadai. Adapun pendekatan kelompok yang telah disebutkan pada penjelasan sebelumnya yaitu focused group discussion atau konseling kelompok problem solving.

Fokus mengenai implementasi nilai-nilai Islam dalam bimbingan dan konseling kelompok, Ibu $\mathrm{S}^{83}$ menyebutkan di sekolahnya, dilakukan bimbingan bentuk kelas (group guidance class) ${ }^{84}$. Para guru BK diberi jam masuk kelas seminggu sekali, sehingga setiap guru BK merancang tema-tema bimbingan yang akan diberikan pada kelomok kelompok kelas termasuk tema-tema keagamaan. Namun tema tersebut disesuaikan dengan kebutuhan siswa yang telah ditelaah melalui angket atau asesmen. Dalam kegiatan tersebut dapat dilakukan bidang layanan pribadi, bidang sosial, bidang belajar, bidang karir. Dengan cara demikian, guru BK bisa melihat langsung kondisi psikologis siswa, meskipun hanya seminggu sekali, sehingga kondisi siswa bisa terkontrol Pelaksanaan program konseling kelompok kelas (group guidance class) dievaluasi untuk dasar perencanaan tindak lanjut. ${ }^{85}$

79. Thomas J. Hernández dan Susan R. Seem, "A Safe School Climate: A Systemic Approach and the School Counselor", Professional School Counseling 7, no. 4 (2004): 256-262.

Abror Sodik, "Konseling Sebagai Suatu Sistem Pendidikan Sekolah", Jurnal Hisbah 13, no.

1 (2016): 1-17.

80. Mulyadi, 348.

81. Wawancara dengan Ibu A pada 2 Agustus 2020

82. Wawancara dengan Pak S pada 14 September 2020

83. Wawancara dengan Ibu S pada 12 Agustus 2020

84. W.S.Winkel \& Sri Hastuti, Bimbingan Dan Konseling Di Institusi Pendidikan (Yogjakarta: Media Abadi, 2006)

85. Wawancara dengan Ibu S pada 12 Agustus 2020 
Ibu $\mathrm{H}$ menjelaskan bahwa sekolahnya merupakan sekolah berbasis asrama. Bimbingan berkelompok dilakukan di masing-masing asrama dilaksanakan oleh pemandu yang merupakan kakak angkatan dan dipantau oleh ibu asrama. Bimbingan berkelompok tersebut berbentuk sholat jama'ah, tadarus al-Qur'an, muhadharah (latihan pidato), dan ceramah agama dari ibu asrama. Kegiatan tersebut dilakukan berasama di asrama. Kegiatan bimbingan di sekolah mendatangkan dari lembaga atau instansi dari luar dalam bentuk penyuluhanpenyuluhan seperti dari dinas kesehatan, kepolisian, dari lembaga perguruan tinggi. ${ }^{86}$

Kegiatan-kegiatan tersebut dapat dipandang sebagai kegiatan-kegiatan bimbingan kelompok (group guidance). ${ }^{87}$ Dari penjelasan tersebut, diketahui bahwa selain bentuk ceramah di kelas, kegiatan-kegiatan keagamaan juga dapat menjadi metode dalam bimbingan kelompok ${ }^{88}$. Hal yang sama, yaitu bimbingan kelompok melalui pengajian juga disebutkan oleh Ibu $G$ dan R. Menurut Ibu $\mathrm{G}^{89}$,

"Bimbingan dan konseling di Sekolah X diadakan melalui pengajian kelas yang diadakan secara bergiliran dirumah siswa-siswi yang berdomisili di Yogyakarta. Acara tersebut, terdiri dari kegiatan pembukaan, tadarus, sambutan tuan rumah dan ketua kelas, pengajian inti, sharing bersama wali kelas, penutup. Jika dilihat dari susunan acara tersebut, maka pada saat pengajian itulah internalisasi nilai nilai religiusitas agama dilakukan.

Wawancara dengan Ibu $\mathrm{R}^{90}$,

"Pengajian kelas bermanfaat baik bagi siswa, guru, maupun orang tual wali. Bagi siswa, mereka bisa silaturahmi langsung kerumah teman, sehingga bisa mengambil bikmah dari apa yang mereka lihat, mereka rasakan, karena keluarga keluarga siswa itu juga bermacam-macam baik tingkat ekonominya, keberagamaannya, dll. Bagi wali kelas dan guru BK, bisa sekalian home visit, silaturahmi dengan orang tua siswa sambil mengobservasi keadaan rumah dan lingkungannya, babkan bisa menanyakan langsung bagaimana kondisi anak saat dirumah. Bagi orang tua ketemu langsung dengan guru BK dan wali kelas merupakan kesempatan yang baik untuk. menanyakan keadaan anaknya ketika di sekolah."

Ibu $\mathrm{B}^{91}$ menceritakan pengalamannya dalam pelaksanaan konseling kelompok sebagai berikut,

86. Wawancara dengan Ibu H pada 9 Juli 2020

87. Margaret E. Bennett, "Group Guidance", Review of Educational Research 9, no. 2 (1939): 217-220. DOI: $10.2307 / 1168013$

88. Ibid.

89. Wawancara dengan Ibu G pada 17 Juli 2020

90. Wawancara dengan Ibu R pada 14 Juli 2020

91. Wawancara dengan Ibu B pada 7 Juli 2020 
"Saya sering melakukan konseling kelompok, 5-7 siswa dengan cara pertama mengidentifikasi masaah masalah siswa. waktu itu masalah 'siswa terlambat masuke sekolah'. Sekitar enam siswa yang memiliki masalah yang sama yakni terlambat masuk. Selanjutnya enam siswa tersebut kita ajak untuk bertemu bersama. Dalam pertemuan tersebut selaku guru BK saya buka dengan do'a terus saya jelaskan mengapa kalian dikumpulkan diforum ini, kemudian mulailab diskusi untuk memecabkan masalah tentang 'terlambat masuk. Setiap siswa berhak mengeluarkan pendapat dan saling memberi masukan. Para siswa juga membacakan dasar dasar dari al-qur'an dan hadits. Dari berbagai macam masukan tersebut, kita berikan analisa kemudian disimpulkean hasil dari pemecahan masalab bersama."

Uraian guru BK tersebut menunjukkan bahwa konseling kelompok itu selain digunakan secara preventif dan pengembangan, bisa dimanfaatkan juga untuk fungsi pemecahan. ${ }^{92}$ Dalam kasus tersebut masalah yang dipecahkan sama yakni "terlambat masuk". Adapun Pak T menjelaskan kegiatan bimbingan dan konseling kelompok di sekolahnya ${ }^{93}$,

"Untuk siswa yang mengalami masalah, biasanya memang dikumpulkan satu kelompok, yaitu yang masalabnya sama, di luar jam kelas. Nanti bersama satu konselor atau guru BK, kelompok siswa tersebut berusaba mendiskusikan masalahnya sehingga bisa mendapatkan ide jalan keluar. Namun selama ini belum ada pengumpulan kelompok untuk diberikan suatu materi tertentu. Dalam kelompoke untuk menyelesaikan masalah tersebut dimulai dengan do'a agar pikiran siswa lebih fokus dan dapat mengikuti kegiatan dengan baik. Selain itu, siswa juga terkadang dianjurkan untuk mendekatkan diri kepada Allah dalam masalah yang sesuai."

Bentuk kelompok yang digunakan yaitu konseling kelompok atau problem solving. ${ }^{94}$ Penjelasan Pak T tersebut dilanjutkan dengan penjelasannya mengenai sistem bimbingan dan konseling di sekolahnya.

"Memang di sekolah itu, penyelesaian masalah awal yaitu di pengasub di asrama. Biasanya guru muda yang tinggal di asrama dan mereka dibantu oleh pemandu atau kakak kelas. Selain itu di asrama juga ada pamong atau wali asrama yaitu guru senior. Ini menjadi tahapan kedua untuk penyelesaian masalah. Jika pamong kesulitan maka bisa diarabkan ke guru BK atau ke wali kelas. Jadi, selain melalui kelas BK, proses pembimbingan justru banyak di asrama, yaitu di pemandu dan pangasub."

Berbagai penjelasan mengenai bimbingan dan konseling kelompok tersebut memperkuat keterangan sebelumnya yaitu implementasi nilai-nilai religiusitas Islam dalam bimbingan dan konseling kelompok dapat berupa nilai-

92. Namora Lumongga Lubis dan Hasnida, Konseling Kelompok (Jakarta: Kencana, 2016), 57.

93. Wawancara dengan Pak T pada 2 September 2020

94. Gibson dan Mithcell, 275; Lubis \& Hasnida, 55. 
nilai tersebut menjadi materi dan dapat pula menjadi metode dalam bimbingan dan konseling tersebut. Sebagaimana yang telah disebutkan, hal ini sesuai dengan kegiatan dalam konseling yang menyesuaikan dengan budaya atau dunia klien. Selain itu, hal ini juga telah sesuai dengan pengembangan Konseling Islam. ${ }^{95}$

Hasil penelitian tersebut dapat kita rangkum. Gambaran implementasi nilai religius pada konseling kelompok yang didapatkan yaitu nilai Islam diterapkan sebagai isi pembicaraan antara konselor dan konseli seperti tema jiwa keagamaan, tingkah laku sesuai tuntunan Islam, shalat tepat waktu, berbagi dengan sesama, akhlak mulia, keimanan kepada Allah dan malaikat, keyakinan kepada hari akhir, dll. Selain itu, implementasi tersebut juga dapat barupa cara menyampaikan pembicaraan kepada konseli atau cara melakukan konseling. Contoh shalat tepat waktu, tuntunan melalui Al-Quran, guru menjadi uswah hasanah (contoh teladan yang baik), membaca (tadarus) Al-Quran, konseli menjalankan ibadah, dan shalat berjamaah. Walaupun cara yang digunakan bersumber dari nilai atau ajaran Islam, tetapi proses konseling juga tetap menggunakan cara atau teknik konseling yang bersifat umum. Tidak ada antipati dari guru mengenai cara atau metode konseling umum. Metode yang dilakukan guru yaitu focused group discussion, pengubahan pola pikir, problem solving, biblioiterapi (secara tidak langsung), pelaksanaan layanan (pribadi, sosial, belajar, dan karir), bimbingan kelompok, penyuluhan seperti dari dinas kesehatan, kepolisian, dari lembaga perguruan tinggi. Selain itu, dilakukan juga konseling yang merupakan gabungan dari konseling umum dan ajaran Islam seperti lewat pengajian sekolah di sekolah atau bergilir di rumah

Penggunaan metode konseling umum yang dipadukan dengan metode dari ajaran Islam juga ditemukan dalam berbagai kajian konseling Islam lain. Rahmi ${ }^{96}$ merumuskan metode konseling Islam secara rinci dengan menggunakan pendekatan umum yang dipadukan dengan ajaran Islam. Contoh yaitu adanya niat untuk memperbaiki diri karena Allah. Penelitian Siregar, Lubis, dan Nur ${ }^{97}$ dilakukan di sebuah sekolah yang diampu di bawah Kementerian Agama. Mereka menemukan di sekolah menengah pertama tersebut, implementasi nilai Islam di dalam konseling yaitu dalam bentuk metode atau teknik. Penerapan tersebut juga dipadukan dengan pendekatan konseling secara umum. Misal, kegiatan konseling dilakukan tidak hanya untuk kurasi/pengobatan tetapi juga pencegahan/prefensi. Selain metode, sebagaimana yang ditemukan dalam penelitian ini, penelitian Siregar, Lubis, dan Nur juga menemukan implementasi

95. Rasool; Mulyadi, 147-148

${ }_{96}$ Alfi Rahmi. Penerapan Model Konseling Islam Dalam Membantu Kesadaran Beragama Pada Remaja Menjadi Pribadi Berakhlakul Karimah. Jurnal At-Taujih: Bingkai Bimbingan dan Konseling Islami 3, no. 2 (2017): 29-38.

${ }^{97}$ Syukur Madani Siregar, Syaiful Akhyar Lubis, Wahyuddin Nur Implementasi Layanan KonselingIslami di Madrasah Tsanawiyah Laboratorium Universitas Islam Negeri. ATTAZAKKI 2, no. 1 (2018): 47-58. 
berbentuk penerapan pemahaman keislaman dalam memahami kondisi siswa sebagai konseli. Dengan kata lain mengimplementasikan nilai religius Islam dalam konten atau isi pembicaraan. Misal kondisi yang siswa yang baik dipahami sebagai kondisi siswa yang berperilaku sesuai ajaran Islam atau dengan kata lain berakhlak mulia.

Hasil tersebut juga mirip dengan yang ditemukan oleh Farihah ${ }^{98}$ dari kajiannya mengenai implementasi nilai Islam pada konseling anak jalanan. Menurutnya, impelentasi Islam pada konseling dengan menggunakan metode yang diambil dari Al-Qur'an Surah An-Nahl ayat 125. Berdasarkan ayat tersebut, terdapat tiga metode konseling yaitu hikmah, pengajaran yang baik, dan tanya jawab yang baik pula. Dalam pengajaran yang baik, konseli diajarkan nilai-nilai Islam yang perlu dilaksanakannya. Pengajaran tersebut ditekankan untuk dilakukan dengan cara yang baik dan tanpa memaksa. Dalam hal ini, implementasi nilai Islam dalam konseling menurut Farihah berupa penggunaan nilai Islam sebagai isi atau konten konseling dan penggunaan metode yang bersumber dari Islam.

Penerapan konseling Islam pada sekolah umum yang tergambarkan dalam penelitian ini agak berbeda dari yang digambarkan oleh Agustina ${ }^{99}$. Berdasarkan hasil penelitian Agustina di suatu sekolah di bawah pengelolaan Dinas Pendidikan, penerapan tersebut cenderung pada penggunaan nilai-nilai Islam dalam proses konseling. Adapun konseling yang dilakukan merupakan bentuk-bentuk konseling secara umum. Walaupun dalam landasan teorinya Agustina menjelaskan kemungkinan menggunakan bentuk-bentuk konseling yang bersumber dari ajaran Islam, tetapi aplikasi hal tersebut tidak tergambar pada penjelasan mengenai pelaksanaan konseling.

Penelitian Rochana yang berupa kajian literatur mengenai konseling Islam juga menjelaskan implementasi nilai Islam hanya dalam penggunaan ajaran Islam untuk menjelaskan kondisi remaja sebagai konseli. Ia menjelaskan berbagai kondisi remaja dapat dijabarkan dengan Al-Quran atau ajaran Islam lain. Hal ini diimplementasikannya dalam konseling mengenai pubertas. Dalam konsepnya terlihat bahwa Rochanah menggunakan ajaran Islam sebagai konten atau isi dari proses konselignya.

${ }^{98}$ Irzum Farihah. Peran Bimbingan Konseling Islam dalam Membangun Keberagamaan Anak Jalanan. KONSELING RELIGI: Jurnal Bimbingan Konseling Islam 4, no. 1 (2013): 145164

${ }^{99}$ Khairia Agustina. Implementasi Layanan Konseling Islami di Sekolah Menengah Atas Negeri 1 Tanjung Tiram Kabupaten Batu Bara. Al-Fatih: Jurnal Pendidikan dan Keislaman II, no.1 (2019): 33-49 
Adapun Al-Qadri, Lubis, dan Hafsah ${ }^{100}$, menjelaskan implementasi nilai Islam para konseling pada tataran cara atau metode konseling yang meliputi empat cara yaitu nasihat, pengajaran, diskusi/debat, dan peringatan. Hal ini sebagaimana yang mereka temukan di sekolah menegah pertama di bawah asuhan Kementerian Agama. Keempat cara tersebut dapat dikatakan sebagai penerapan cara-cara atau metode Islam dalam proses konseling.

\section{Penutup}

Berdasarkan penjelasan pada bagian hasil dan pembahasan, didapatkan kesimpulan bahwa guru BK yang menjadi informan dalam penelitian ini telah memiliki pemahaman mengenai nilai-nilai religius yang memadai. Mereka mampu menjelaskan nilai-nilai keyakinan (aqidah), perilaku (akhlak), dan aturan (syariat). Mereka memiliki semangat meningkatkan pengetahuan mengenai nilai religiusitas Islam dan hal ini juga didukung oleh sekolah mereka. Guru BK tersebut mendapatkan pemahaman nilai religius Islam dengan bergabung dalam organisasi Islam dan cenderung aktif dalam kegiatan keislaman. Selain itu, guru BK juga mendapatkan pemahaman mengenai nilai-nilai Islam dari membaca majalah, buku, surat kabar, diskusi, pengajian, serta kegiatan pendidikan keislaman (training, workshop, atau pelatihan). Mereka juga memiliki religiusitas yang baik dalam hal pengalaman (aspek konsekuensial).

Pemahaman mengenai nilai-nilai religius tersebut diimplementasikan ke dalam bimbingan konseling kelompok oleh para guru tersebut. Implementasi tersebut dalam bentuk (a) menjadikan nilai keislaman sebagai materi atau konten yang disampaikan dalam bimbingan dan konseling. Nilai tersebut seperti akhak yang baik (perilaku), keyakinan kepada Allah (aqidab), keyakinan kepada Hari Akhir (aqidah), dan keyakinan kepada malaikat. Selain itu, implementasi juga dalam bentuk (b) menjadikan nilai keislaman sebagai metode atau teknik dalam bimbingan dan konseling kelompok, seperti grup guidance class dengan kegiatan ibadah bersama atau pengajian keagamaan, dan konseling kelompok dengan doa dan ibadah.

Nilai-nilai religiusitas terlihat dapat diterapkan dalam proses bimbingan dan konseling kelompok. Walaupun demikian, efektivitas penerapan nilai-nilai tersebut perlu dipelajari lebih jauh, termasuk penerapan nilai-nilai suatu agama, khususnya Islam, di dalam suatu lingkungan yang lebih heterogen. Dua hal tersebut, juga berbagai hal yang belum dicapai lainnnya dalam penelitian ini dapat dikaji dalam penelitian selanjutnya.

100 Muamar Al Qodri, Saiful Akhyar Lubis, dan Hafsah. Implementasi Layanan Konseling Islami Dalam Pembinaan Kesehatan Mental Siswa di MTsN Tanjung Pura. Edu Riligia 1, no. 3 (2017): 397-413. 


\section{Daftar Pustaka}

"Abkin tegaskan Indonesia butuh 129.000 guru BK," Asosiasi Bimbingan dan Konseling, 29 Agustus 2013, https://www.abkin.org/news/read/96/abkin-tegaskan-indonesiabutuh-129000-guru-bk.html

Agustina, K. (2019) Implementasi Layanan Konseling Islami di Sekolah Menengah Atas Negeri 1 Tanjung Tiram Kabupaten Batu Bara. Al-Fatib: Jurnal Pendidikan dan Keislaman, II(1): 33-49.

Al Qodri,M., Lubis, S.A., \& Hafsah (2017) Implementasi Layanan Konseling Islami Dalam Pembinaan Kesehatan Mental Siswa di MTsN Tanjung Pura. Edu Riligia: Vol. 1(3): 397-413. doi: 10.47006/er.v1i3.1053

Ancok, D., \& Suroso, F. N. Psikologi Islami: Solusi Islam atas Problem-problem Psikologi. Yogyakarta: Pustaka Pelajar, 2011.

Ardi, Z. \& Sisin, M. (2018) The Contribution of Assertive Technique Behavioral Counseling to Minimize the Juvenile Delinquency Behavior. Jurnal Konseling dan Pendidikan, 6(2): 67-77. doi: 10.29210/127400

Azis, A. R. (2015) Efektivitas Pelatihan Asertivitas untuk Meningkatkan Perilaku Asertif Siswa Korban Bullying," Jurnal Konseling dan Pendidikan 3,(2): 8-14. doi: $10.29210 / 12500$

Badan Penelitian dan Pengembangan Kesehatan Kementerian Kesehatan RI, Laporan Riset Kesehatan Dasar 2018. Jakarta: Kementrian Kesehatan Republik Indonesia, 2018.

Badan Pusat Statistik, Penduduk Indonesia: Hasil Sensus Penduduk Indonesia 2010. Jakarta: Badan Pusat Statistik, 2010.

Bennett, M.E. (1939) Group Guidance. Review of Educational Research, 9(2): $217-$ 220.

Corey, G. Theory and Practice of Counseling and Psychotherapy, Tenth Edition. Boston: Cengage Learning, 2016.

Corrieri, S. Heider, D., Conrad, I, \& Blume, A. (2013) School-based prevention programs for depression and anxiety in adolescence: A systematic review. Health Promotion International, 29(3): 1-15. doi: 10.1093/heapro/dat001

Farihah, I. (2013). Peran Bimbingan Konseling Islam dalam Membangun Keberagamaan Anak Jalanan. KONSELING RELIGI: Jurnal Bimbingan Konseling Islam, 4(1): 145- 164. doi: 10.21043/kr.v4i1.1074.

Fatchurahman, M., Syarif, D.F. T., Turohmi, S. (2018) Efektivitas Layanan Konseling Kelompok Menggunakan Teknik Problem Solving Dalam 
Menurunkan Perilaku Membolos Siswa", Indonesian Journal of Educational Counseling, 2(1): 55-68. doi: 10.30653/001.201821.18

Gibson, R. L. \& Mithcell, M.H. Bimbingan dan Konseling Edisi Ketujuh, Terj. Yudi Santoso. Pustaka Pelajar: Yogyakarta, 2011.

Habsy, B.A. (2017) Model Konseling Kelompok Cognitive Behavior Untuk Meningkatkan Self-Esteem Siswa SMK. PERSPEKTIF Ilmu Pendidikan,31(1): 21-35. doi: 10.21009/PIP.311.4

Hassan, A. E. H. (2015) Effectiveness of School Counseling program Based on counseling Activities to Support Mental Health among Basic School Pupils. International Journal of Education and Research 3,(4): 393-400.

Hernández, T.J. \& Seem, S.R. (2004). A Safe School Climate: A Systemic Approach and the School Counselor. Professional School Counseling, 7(4): 256-262.

Hidayat, D. R. Konseling di Sekolab: Pendekatan-pendekatan Kontemporer. Jakarta: Prenada Media, 2018.

Ismail, A. U. (2021) Integrasi Syariah dengan Tasawnf” Abkam, XII(1): 29-138. doi: 10.15408/ajis.v12i1.987

"Kekerasan Remaja Indonesia Mencapai 50 Persen," Fakultas Kedokteran, Kesehatan Masyarakat, dan Keperawatan UGM online, 14 Maret 2018, https://fk.ugm.ac.id/kekerasan-remaja-in donesia-mencapai-50-persen/

Lee, C.C. Elements of culturally competent counseling (ACAPCD-24). Alexandria, VA: American Counseling Association, 2008.

Lubis N.L., \& Hasnida, Konseling Kelompok. Jakarta: Kencana, 2016.

Luki Aulia, "Sekolah Kekurangan 92.572 Guru Konseling," 23 Januari 2013, https://edukasi.kompas.com/read/2013/01/23/11190821/Sekolah.Ke kurangan.92.572.Guru.Konseling.

McLeod, J. Introduction to Counselling, Fifth Edition. New York: Open University Press, 2013.

"Meningkatnya Gangguan Mental pada Remaja, Apakah Terlalu Lama Sekolah di Rumah?" Harian Pikiran Rakyat online, 23 Juli 2020, https://jakpusnews.pikiran-rakyat.com/kesehatan/pr44632663/meningkatnya-gangguan-mental-pada-remaja-apakah-terlalulama-sekolah-di-rumah

Mulyadi, Bimbingan Konseling di Sekolah dan Madrasah. Jakarta: Prenadamedia Grop, 2019.

Perkasa, G. "Tak Hanya Orang Dewasa, Anak Remaja Pun Bisa Mengalami Gangguan Mental", diubah terkahir 23 Juli 2020, 
https://lifestyle.kompas.com/read/2020/07/23/191950120/tak-hanyaorang-dewasa-anak-remaja-pun-bisa-mengalami-gangguanmental?page $=$ all.

Puslitdatin, "Penggunaan Narkotika di Kalangan Remaja Meningkat," terakhir diubah 12 Agustus 2019, https://bnn.go.id/penggunaan-narkotikakalangan-remaja-meningkat/

Putra, H. P., Gistituati, N \& Syahniar. (2015). Peningkatan Perilaku Prososial Siswa di Sekolah melalui Layanan Bimbingan Kelompok dengan Teknik Modeling. Jurnal Konseling dan Pendidikan, 3(2): 31-39. doi: $/ 10.29210 / 112700$

Rachman, T. "Indonesia Butuh 129 Ribu Guru Bimbingan Konseling." terakhir diubah 30 Agustus 2013 , https://republika.co.id/berita/pendidikan/eduaction/13/05/30/mnkhv $\mathrm{n}$-indonesia-butuh-129-ribu-guru-bimbingan-konseling

Rahmi, A. (2017) Penerapan Model Konseling Islam Dalam Membantu Kesadaran Beragama Pada Remaja Menjadi Pribadi Berakhlakul Karimah. Jurnal At-Taujib: Bingkai Bimbingan dan Konseling Islami, 3(2): 2938. doi: $10.15548 /$ atj.v3i2.530

Rassool, G.H. Islamic Counselling: An Introduction to Theory and Practice. East Sussex: Routledge, 2016.

Rochanah (2018) Implementasi Landasan Religius dalam Kegiatan Bimbingan dan Konseling Sebagai Upaya Penanganan Dampak Masa Puber. Konseling Edukasi: Journal of Guidance and Counseling, 2(1): 21-42. doi: 10.21043/konseling.v2i1.3884

Santrock, J.W. Adolescence, Sixteenth Edition. New York: McGraw-Hill Education, 2016.

Siregar, S.M., Lubis, S.A., Nur, W. (2018) Implementasi Layanan KonselingIslami di Madrasah Tsanawiyah Laboratorium Universitas Islam Negeri. AT-TAZAKKI, 2(1): 47-58.

Sodik, A. (2016) Konseling Sebagai Suatu Sistem Pendidikan Sekolah. Jurnal Hisbah, 13 (1): 1-7.doi: 10.14421/hisbah.2016.131-01

Sue, S., Zane, N., Hall, G.C.N., \& Berger, L.K. (2009) The Case for Cultural Competency in Psychotherapeutic Interventions. Annual Review of Psychology, 60.

Syaltut, M. Islam Aqidah wa Syari'ah. Kairo: Dar al-Qalam, 1966.

Wenar, C., Kerig, P. \& Ludlow, A. Developmental Psychopathology: From Infancy Through Adolescence. New York: McGraw-Hill Education, 2012. 
Wijaya, C.A. "Most crimes in Jakarta committed by youngsters: Research," terakhir diubah 22 Juni 2017, https://www.thejakartapost.com/news/2017/06/22/most-crimes-injakarta-committed-by-youngsters-research.html.

Winkel, W.S. \& Hastuti, S. Bimbingan Dan Konseling Di Institusi Pendidikan. Yogjakarta: Media Abadi, 2006.

Zarkasyi, H. F. Minhaj: Berislam, dari Ritual bingga Intelektual. Jakarta: Inisist, 2020. 
42 | Islamic Counseling: Jurnal Bimbingan dan Konseling Islam, Vol. 5, No. 1, 2021

Halaman ini Sengaja Dikosongkan 